\title{
Peran Media Audio dalam Meningkatkan Kualitas Proses Pembelajaran Apresiasi Cerita Pendek
}

\section{Andi Wicaksono}

IAIN Surakarta

\begin{abstract}
Learning innovation is an important thing to be possessed by the teacher. This is because, through the update that is later success in learning objectives can be delivered optimally. As one of these innovations is the use of learning media. This study was conducted to reveal the effectiveness of the use of audio media in the form of recording readings of short stories on the quality of the learning process of appreciation of the short story. This study used qualitative research methods class action, this study resulted in a conclusion that the audio media can improve the quality of the learning process of short stories with three benchmarks, namely the increasing activity of students during the activity apersepsi, the increased activity of students during the teaching and learning activities, and increased courage students to present the results of its work in the discussion forum.
\end{abstract}

\begin{abstract}
Abstrak
Inovasi pembelajaran adalah satu hal penting yang harus dimiliki oleh pengajar. Hal ini, disebabkan melalui pembaruan itulah, kemudian keberhasilan tujuan dalam pembelajaran dapat tersampaikan secara optimal. Adapun salah satu inovasi tersebut adalah dengan pemanfaatan media pembelajaran. Studi ini dilakukan untuk mengungkap efektivitas dari pemanfaatan media audio yang berupa rekaman pembacaan cerita pendek terhadap kualitas proses pembelajaran apresiasi cerita pendek. Dengan pendekatan kualitatif secara metode penelitian tindakan kelas, studi ini menghasilkan sebuah simpulan bahwa media audio dapat meningkatkan kualitas proses pembelajaran cerita pendek dengan tiga tolok ukur, yaitu meningkatnya keaktifan siswa selama mengikuti kegiatan apersepsi, meningkatnya keaktifan siswa selama mengikuti kegiatan belajar-mengajar, dan meningkatnya keberanian siswa untuk mengemukakan hasil pekerjaannya dalam forum diskusi.
\end{abstract}

Keywords: audio media role, learning process, short story appreciation DOI: $10.22515 /$ shahih.v2i1.670

\section{Coressponding author}

Email: bijakmanyar@gmail.com 


\section{Pendahuluan}

Bahasa Indonesia merupakan salah satu mata pelajaran penting di Indonesia. Hal ini terbukti dari sekian banyak mata pelajaran yang diajarkan, Bahasa Indonesia menjadi salah satu materi Ujian Nasional (UN) pada berbagai jenjang pendidikan dasar dan menengah. Hanya saja, kenyataan ini tidak diikuti dengan keseriusan dari pemangku kepentingan dalam memperbaiki permasalahan yang terjadi di lapangan.

Pada kenyataannya, mata pelajaran Bahasa Indonesia tidak hanya mengajarkan tentang materi kebahasaan saja, tetapi juga meliputi materi kesastraan. Keduanya telah direncanakan mendapatkan porsi yang seimbang, sehingga tidak ada salah satu bidang yang dianakemaskan. Namun, di lapangan, pengajaran mata pelajaran Bahasa Indonesia tidak sesuai dengan apa yang telah direncanakan. Para guru lebih memprioritaskan materi kebahasaan daripada materi kesastraan. Apalagi jika dikaitkan dengan Ujian Nasional, anggapan tersebut semakin diperkuat, karena kebanyakan soal yang muncul adalah berkenaan dengan kompetensi berbahasa siswa.

Pengajaran sastra sebenarnya tidak hanya mencetak manusia menjadi sastrawan saja, sastra bisa menjadi medium untuk mengasah dan mengembangkan keterampilan berbahasa siswa. Selain itu, pengajaran apresiasi sastra, salah satunya cerita pendek sebenarnya tidak hanya bermanfaat untuk menunjang keterampilan berbahasa siswa, melainkan juga untuk memperkaya pengalaman, pandangan hidup, dan kepribadian siswa. Hal ini sesuai dengan pernyataan Ismail bahwa wacana sastra bermanfaat untuk pembentukan kepribadian, mengasah intuisi, dan kepekaan sosial siswa yang pada umumnya memasuki tahap pertumbuhan (Ismail, 2007, p. 5).

Di sisi lain, sastra pun bisa menjadi media pendidikan karakter pada peserta didik. Melalui media sastra, penanaman budi pekerti bisa tersampaikan kepada peserta didik. Hal tersebut diaminkan oleh Lickona, pakar pendidikan karakter dari Amerika Serikat ini pernah menyampaikan di dalam tulisannya bahwa sastra adalah materi pembelajaran yang sangat penting dalam pendidikan karakter, karena memiliki kekuatan sebagai guru moral. Oleh karena itu, Lickona kemudian menekankan untuk senantiasa mengenalkannya kepada peserta didik di semua jenjang pendidikan (Lickona, 2013).

Di dalam khazanah keislaman pun pentingnya penanaman budi pekerti kepada anak senantiasa ditekankan. Setidaknya, hal ini telah tersurat di dalam ayat-ayat suci Alquran maupun sabda Nabi. Karena itu, tidak heran jika Muqtadir menyampaikan, "Orang yang berbudi pekerti baik adalah orang terbaik." (Muqtadir, 2008, p. 210). Lebih jauh kemudian, ia mengorelasikan antara iman dengan budi pekerti, sehingga semakin baik budi pekerti seseorang maka semakin sempurna imannya (Muqtadir, 2008). Oleh karena itu, di samping sebagai materi pembelajaran, mengkaji karya sastra terutama cerita pendek juga bisa 
mendukung penanaman pendidikan karakter. Asalkan, cerita pendek yang dipilih pun tepat untuk perkembangan peserta didik.

Cerita pendek sebagai salah satu genre sastra fiksi yang sangat menarik untuk dibaca dan dipelajari. Cerita pendek tergolong dalam cerita rekaan. Menurut Abrams cerita pendek dikatakan sebagai cerita rekaan karena isinya tidak menyaran pada kebenaran sejarah (Nurgiyantoro, 2005).

Hanya saja, dalam pelaksanaan pembelajaran apresiasi cerita pendek seringkali masih dijumpai guru memakai cara-cara konvensional, baik penggunaan metode belajar ataupun penggunaan media dalam belajar. Hal tersebut, akan berakibat menurunnya motivasi siswa dalam mempelajari materi. Pada akhirnya, pembelajaran berjalan monoton dan miskin kreativitas sehingga, pesan-pesan moral yang terkandung di dalam karya sastra besar kemungkinan tidak tersampaikan kepada peserta didik. Hal ini senada dengan pernyataan Wijayanti di dalam artikelnya yang menyimpulkan bahwa melalui inovasi pembelajaran, maka tujuan dalam pembelajaran pun dapat tersampaikan secara optimal (Wijayanti, 2016).

Inovasi pembelajaran, hendaknya senantiasa diterapkan oleh pengajar pada semua jenjang pendidikan. Proses pembelajaran akan terlihat tampak lebih hidup ketika guru bisa mengeksplorasi secara maksimal semua unsur di sekitarnya. Hal ini sesuai dengan pernyataan Hamalik bahwa pembelajaran merupakan suatu kombinasi yang tersusun meliputi unsur-unsur manusiawi, material, fasilitas, perlengkapan, dan prosedur yang saling memengaruhi dalam mencapai tujuan pembelajaran. Material meliputi buku-buku, papan tulis, kapur; fotografi, slide dan film, audio dan video tape. Fasilitas dan perlengkapan terdiri dari ruangan kelas, perlengkapan audio visual, serta komputer. Prosedur meliputi jadwal dan metode penyampaian informasi, praktik, belajar, ujian, dan sebagainya (Hamalik, 2003, p. $57)$.

Oleh karena itu, penulis menyusun arikel ini dengan tujuan memberikan gambaran tentang pentingnya pemanfaatan media audio sebagai salah satu sumber belajar siswa. Pembelajaran apresiasi cerita pendek yang berlangsung di dalam kelas dengan memanfaatkan media yang sesuai, dapat memacu kreativitas dan antusias siswa dalam mengikuti pembelajaran. Pemanfaatan media belajar yang relevan dengan materi belajar, juga dapat memberikan pengalaman belajar yang sangat dibutuhkan siswa dalam mengonstruksi sebuah pengetahuan kebahasaan.

Adapun media audio dipilih berdasarkan kenyataan di lapangan bahwa konsep belajar pada dasarnya mengonstruksi lingkungannya. Seringkali kita jumpai, bahwa kebiasaan bercerita secara lisan lebih diminati oleh masyarakat daripada secara tertulis. Pada akhirnya, pemanfaatan media audio yang berupa rekaman pembacaan cerita pendek, dapat dijadikan media dalam pembelajaran apresiasi cerita pendek. 
Adapun mengenai pemanfaatan media audio dalam meningkatkan kualitas pembelajaran, sebelumnya Safitri telah melakukan penelitian dan menghasilkan sebuah simpulan bahwa rekaman pembacaan ayat suci Alquran atau murottal (yang notabene merupakan bentuk media pembelajaran audio) pun ternyata dapat meningkatkan kualitas pembelajaran melafalkan surat pendek (Safitri, 2013). Oleh karena itu, tentunya hasil penelitian tersebut perlu ditindaklanjuti untuk diterapkan pula dalam pembelajaran bahasa dan sastra Indonesia, sehingga hasil dari karya tulis ini akan menawarkan kebaruan dalam pembelajaran Bahasa Indonesia, terutama pada jenjang SMA.

\section{Penelitian Tindakan Kelas}

Artikel ini berdasarkan hasil penelitian penulis yang telah dilaksanakan terlebih dahulu. Adapun metode penelitiannya adalah penelitian tindakan kelas (Classroom Action Research), yaitu sebuah penelitian yang merupakan kerjasama antara peneliti, guru, siswa, dan staf sekolah yang lain untuk menciptakan suatu kinerja sekolah yang lebih baik. Penelitian tindakan kelas merupakan suatu pencermatan terhadap kegiatan belajar berupa sebuah tindakan yang sengaja dimunculkan dan terjadi dalam sebuah kelas secara bersama. Dalam pelaksanaannya, penelitian ini membutuhkan kerja sama aktif antara peneliti, guru, siswa, dan staf sekolah untuk menciptakan pembelajaran yang lebih baik (Arikunto, 2007, p. 3).

Penulis yang dalam hal ini berkedudukan sebagai peneliti berusaha mengamati dan mendeskripsikan permasalahan-permasalahan yang dialami guru dalam pembelajaran apresiasi cerita pendek. Berdasarkan hasil pengamatan itulah, kemudian penulis memberikan alternatif usaha guna mengatasi permasalahan tersebut. Alternatif usaha tersebut, diharapkan mampu memberikan kontribusi ke arah perbaikan pembelajaran apresiasi cerita pendek di kelas yang dalam hal ini dilaksanakan pada siswa kelas XI IA 2 SMA Batik 1 Surakarta.

Proses dasar penelitian tindakan kelas didasarkan atas menyusun rencana tindakan bersama, bertindak dan mengamati secara individual dan bersama-sama pula, kemudian mengadakan refleksi atas berbagai kegiatan yang telah dilakukan (Madya, 2006, p. 59). Dalam penelitian ini, peneliti bersama-sama guru Bahasa Indonesia sebagai pemegang otoritas pengajaran di dalam kelas menyusun rencana tindakan bersama. Kemudian, peneliti bersama guru melaksanakan tindakan berdasarkan rencana tindakan yang telah disepakati bersama. Kegiatan pelaksanaan tersebut diikuti pula dengan kegiatan pemantauan segala kejadian di dalam kelas. Apabila dirasa kurang maksimal, peneliti mulai menentukan perencanaan selanjutnya untuk siklus berikutnya. Adapun penjabaran prosedur dari penelitian tindakan kelas adalah sebagai berikut: 


\section{Perencanaan Tindakan}

Tahapan ini berupa menyusun rancangan tindakan yang menjelaskan tentang apa, mengapa, kapan, di mana, oleh siapa, dan bagaimana tindakan tersebut akan dilakukan (Suhardjono, 2006, p. 75). Dari hasil pengidentifikasian dan penetapan masalah, kemudian diambilah suatu solusi alternatif melalui media audio yang berupa pembacaan cerita pendek dalam pembelajaran apresiasi cerita pendek.

2. Pelaksanaan Tindakan

Pada tahap ini, rancangan strategi dan skenario yang telah disusun mulai diterapkan. Rencana tindakan tersebut tentu saja sebelumnya telah dilatihkan kepada si pelaksana tindakan (guru) untuk dapat diterapkan di dalam kelas sesuai dengan skenarionya. Skenario tindakan harus dilaksanakan dengan baik dan wajar (Suhardjono, 2006, pp.76$77)$.

3. Pengamatan atau observasi

Tahap ini sebenarnya berjalan bersamaan dengan saat pelaksanaan dilakukan. Pengamatan dilakukan pada waktu tindakan sedang berjalan, jadi keduanya berlangsung dalam waktu yang sama. Pada tahap ini, peneliti melakukan pengamatan dan mencatat semua hal yang diperlukan dan terjadi selama pelaksanaan tindakan berlangsung (Suhardjono, 2006, p. 78). Dalam tahap ini dilakukan dengan cara peneliti bertindak sebagai partisipan pasif yang mengamati jalannya pembelajaran di kelas yang dipimpin oleh guru. Berbagai perkembangan proses belajar siswa terus diamati dan tercatat pada catatan lapangan yang dilakukan setiap kali pengambilan data dilaksanakan.

4. Refleksi

Tahapan ini dimaksudkan untuk mengkaji secara menyeluruh tindakan yang telah dilakukan, berdasarkan data yang telah terkumpul, kemudian dilakukan evaluasi guna menyempurnakan tindakan berikutnya. Refleksi dalam penelitian tindakan kelas mencakup analisis, sintesis, dan penilaian terhadap hasil pengamatan atas tindakan yang dilakukan (Suhardjono, 2006, p. 80). Hasil evaluasi kemudian dianalisis untuk menentukan langkah-langkah perbaikan apa yang dapat ditempuh, sehingga didapatkan suatu solusi untuk semua permasalahan yang dialami oleh guru dan siswa dalam pembelajaran apresiasi cerita pendek dengan media audio berupa pembacaan cerita pendek. Tahapan berikutnya, ditariklah sebuah simpulan yang berupa hasil dari pelaksanaan tindakan. Dari hasil pengambilan kesimpulan ini, dapat diketahui apakah peneliti berhasil atau tidak sehingga dapat menentukan langkah selanjutnya. Berikut akan disampaikan gambar alur penelitian tindakan kelas. 


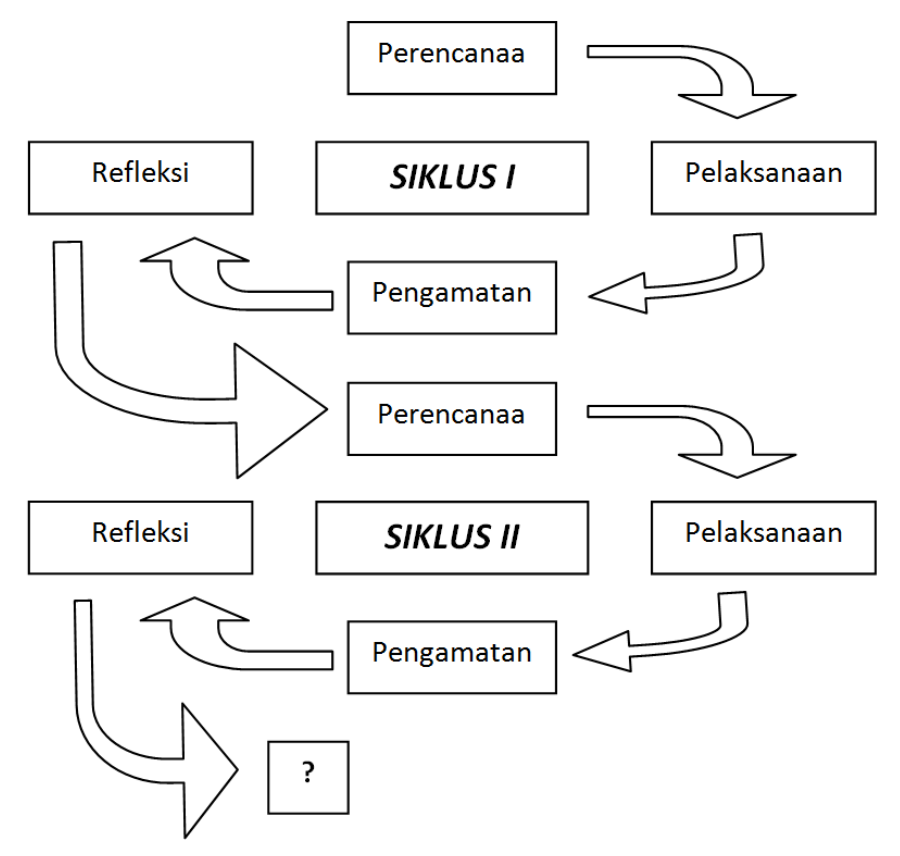

Gambar 1. Alur Penelitian Tindakan

Pada dasarnya, suatu penelitian tindakan kelas dikatakan berhasil jika tindakan yang dilakukan dapat mencapai tujuan yang telah disepakati antara guru dengan peneliti. Oleh karena itu, perlu adanya indikator keberhasilan yang nantinya menjadi tolok ukur dari penelitian. Adapun indikator keberhasilan yang telah disepakati antara penulis dengan guru mata pelajaran adalah sebagai berikut:

\begin{tabular}{|c|c|c|c|}
\hline No. & Kegiatan Siswa & $\begin{array}{c}\text { Persentase } \\
\text { Siklus IJI }\end{array}$ & Cara Mengukur \\
\hline 1. & Aktif selama apersepsi & $70 \%$ & $\begin{array}{l}\text { Diamati saat pembelajaran dengan } \\
\text { menggunakan lembar observasi oleh } \\
\text { peneliti dan dihitung dari jumlah siswa } \\
\text { yang menampakkan kesungguhan dalam } \\
\text { pelajaran. }\end{array}$ \\
\hline 2. & $\begin{array}{l}\text { Aktif selama mengikuti } \\
\text { pelajaran }\end{array}$ & $70 \%$ & $\begin{array}{l}\text { Diamati saat pembelajaran dengan } \\
\text { menggunakan lembar observasi oleh } \\
\text { peneliti dan dihitung dari jumlah siswa } \\
\text { yang menampakkan kesungguhan dalam } \\
\text { pelajaran. }\end{array}$ \\
\hline 3. & $\begin{array}{l}\text { Berani membacakan } \\
\text { hasil pekerjaan dalam } \\
\text { forum diskusi. }\end{array}$ & $70 \%$ & $\begin{array}{l}\text { Diamati saat pembelajaran dengan } \\
\text { menggunakan lembar observasi oleh } \\
\text { peneliti dan dihitung dari jumlah kelompok } \\
\text { yang mampu menjalin kerja sama dalam } \\
\text { kelompoknya dan berani membacakan } \\
\text { pekerjaan. }\end{array}$ \\
\hline
\end{tabular}

Tabel 1. Indikator Keberhasilan 
Pada dasarnya, penelitian tindakan kelas adalah salah satu metode penelitian kualitatif. Oleh karena itu, secara garis besar teknik analisis datanya pun tidak jauh berbeda dengan penelitian kualitatif. Setelah data di lapangan terkumpul dengan berdasarkan prosedur yang telah disebut di atas, penulis kemudian menganalisisnya dengan menggunakan teknik analisis interaktif yang dikembangkan oleh Miles dan Huberman. Analisis interaktif tersebut terdiri atas tiga komponen kegiatan yang saling terkait satu sama lain: reduksi data, beberan (display) data, dan penarikan kesimpulan (Madya, 2006).

Reduksi data diperoleh dengan cara menyeleksi, menentukan fokus, menyederhanakan, meringkas, dan mengubah bentuk data mentah yang ada dalam catatan lapangan dalam pembelajaran apresiasi cerita pendek. Setelah direduksi, data siap dibeberkan. Berbagai data tentang pembelajaran apresiasi cerita pendek yang telah direduksi dibeberkan dengan tertata rapi dalam bentuk narasi atau pun tabel-tabel. Pembeberan data tersebut, akan memudahkan dalam penarikan kesimpulan atau menentukan tindakan selanjutnya.

\section{Hasil}

Sesuai dengan apa yang telah dijabarkan sebelumnya, bahwa sebuah penelitian tindakan kelas dinyatakan berhasil jika batas minimal indikator keberhasilan yang telah dirumuskan dan disepakati telah tercapai. Adapun dalam konteks penelitian ini, akhirnya tindakan terlaksana menjadi tiga siklus. Hal ini disebabkan, pada siklus ketiga, akhirnya ketuntasan pada semua indikator telah tercapai.

Selama proses tindakan berlangsung, penulis berperan sebagai partisipan pasif dengan memilih tempat duduk di belakang. Tentunya kehadiran penulis pada awalnya mengundang rasa penasaran siswa. Oleh karena itu, guru sejak pratindakan memiliki peran penting dalam menjelaskan tentang siapa penulis agar pada saat tindakan tidak mengganggu jalannya proses pembelajaran.

\section{Siklus pertama}

Pada siklus pertama, sebenarnya peningkatan kualitas pembelajaran sudah mulai tampak. Antusiasme siswa dalam mengikuti jalannya proses belajar mengajar meningkat dibandingkan dengan kondisi awal sebelum adanya tindakan. Pada siklus ini, media pembacaan cerita pendek yang dipilih adalah pembacaan cerita pendek karya M. Fudoli Zaini yang berjudul "Warisan." Pada pertemuan ini, tiap siswa kemudian ditugasi untuk mengidentifikasi unsur-unsur intrinsik yang terkandung di dalam pembacaan cerita pendek tersebut lalu didiskusikan secara klasikal.

Setelah siklus pertama berakhir, kemudian penulis melakukan wawancara tidak terstruktur kepada dua orang siswa yang dipilih secara random. Adapun respons siswa terhadap pemanfaatan media audio dalam siklus pertama bahwa siswa menyukai 
pemanfaatan rekaman pembacaan cerita pendek sebagai media dalam pembelajaran apresiasi cerita pendek. Namun, mereka menyayangkan adanya kualitas suara yang kurang bagus. Mereka menganggap rekaman tersebut terlalu cepat dan kurang keras.

\section{Siklus kedua}

Berdasarkan proses evaluasi dan masukan dari siswa dalam wawancara yang tidak terstruktur, maka siklus kedua pun dilaksanakan. Selain itu, meski sudah tampak adanya perkembangan, tapi hal itu belum bisa mencapai batas minimal indikator keberhasilan. Maka dari itu, pada siklus kedua kemudian dilakukanlah kembali penelitian tindakan tersebut dengan menjadikan rekaman pembacaan cerita pendek karya Putu Wijaya yang berjudul "Pensiunan" sebagai media pembelajaran.

Kali ini, kelas kemudian dibagi menjadi enam kelompok kecil. Pada pertemuan ini, siswa tampak antusias karena pembacaan cerita pendek yang diperdengarkan tersebut mengandung sedikit unsur humor, sehingga pembelajaran pun berlangsung lebih menyenangkan. Siswa menyimak secara berkelompok lalu membuat parafrase dan menunjukkan tahapan plot dari materi pembacaan cerita pendek tersebut secara bersamasama. Guru memonitor keaktifan siswa dengan mendatangi kelompok-kelompok tersebut. Kemudian guru beserta siswa berdiskusi membahas hasil pekerjaan masing-masing kelompok. Guru memberikan reward pada siswa yang mau berkomentar dalam diskusi tersebut.

Usai pembelajaran, kemudian penulis kembali melakukan wawancara tidak terstruktur kepada siswa. Berdasarkan wawancara tersebut, dapat diketahui bahwa siswa merasa kurang berkonsentrasi dalam menyimak rekaman pembacaan cerita pendek yang diperdengarkan. Hasil wawancara tidak berstruktur yang diberikan pada siswa menyatakan siswa tidak dapat berkonsentrasi penuh karena adanya keramaian di luar kelas. Hal tersebut dapat menjadi sebuah kendala bagi siswa. Meski demikian, siswa menyukai pemanfaatan rekaman pembacaan cerita pendek sebagai media dalam pembelajaran apresiasi cerita pendek.

\section{Siklus ketiga}

Memasuki siklus ketiga, atas dasar kendala pada siklus sebelumnya maka pembelajaran pun akhirnya dilaksanakan di ruang audio visual. Hal ini disebabkan, ruangan tersebut telah disetting kedap suara, sehingga suara gaduh dari luar kelas pun tidak dapat terdengar dari dalam ruangan. Selain itu, pada ruang ini telah tersedia perangkat yang bisa mendukung pembelajaran menyimak, sehingga kualitas bahan simakan pun dapat disajikan secara optimal.

Adapun media audio yang diperdengarkan pada siklus ketiga adalah pembacaan cerita pendek yang berjudul "Di Sini Jualan Ikan Segar" karya Andi Wicaksono. Hasil 
yang diharapkan pada kegiatan siklus ketiga ini adalah siswa mampu menemukan dan mencatat kelebihan serta kekurangan dari sebuah cerita pendek. Penugasan ini dilakukan secara mandiri. Hal ini, dilakukan atas dasar siswa dirasa telah mampu bekerja secara mandiri dari hasil pengalaman belajar siswa sebelumnya secara berkelompok. Guru memonitor keaktifan siswa dengan mendatangi siswa yang terlihat kesulitan mengerjakan. Kemudian, guru beserta siswa berdiskusi membahas hasil pekerjaan mandiri siswa. Guru memberikan reward pada siswa yang mau berkomentar dalam diskusi tersebut. Setelah itu, guru bersama dengan siswa melakukan refleksi terhadap keseluruhan materi pembelajaran apresiasi cerita pendek. Sebelum ditutup, guru masih memberikan kesempatan bertanya kepada siswa. Setelah semua terlaksana, guru menutup pelajaran pada hari itu.

Adapun respons siswa terhadap media audio berupa, rekaman pembacaan cerita pendek dalam siklus ketiga adalah siswa menyukai pemanfaatan rekaman pembacaan cerita pendek sebagai media dalam pembelajaran apresiasi cerita pendek.

\section{Pembahasan}

Keberhasilan proses belajar mengajar dapat ditandai dengan adanya perubahan tingkah laku atau sikap pada diri siswa terhadap suatu materi. Penggunaan media pembelajaran yang tepat, sangat menentukan keberhasilan sebuah pembelajaran. Hal ini disebabkan, karena setiap media pembelajaran memiliki karakteristik yang berbeda.

Pemanfaatan media audio dalam pembelajaran apresiasi cerita pendek, ternyata dapat meningkatkan kegiatan belajar mengajar. Melalui media audio, siswa menjadi lebih aktif dalam kegiatan belajar mengajar. Keaktifan itu disebabkan media audio mengandung unsur kebaruan dalam pembelajaran. Selain itu, media audio yang dalam penelitian ini berupa pembacaan cerita pendek juga bisa menjadi modelling bagi siswa.

Selama tindakan, mulai dari siklus pertama hingga siklus ketiga, media audio yang berupa pembacaan cerita pendek selalu mengalami perbaikan. Hingga akhirnya di siklus ketiga kualitas media audio tersebut semakin mendekati sempurna. Adapun cara penulis untuk mengetahui baik buruknya media tersebut adalah melalui wawancara terstruktur kepada siswa yang dilakukan pada tiap akhir pertemuan.

Selain media yang dapat menunjang pembelajaran, guru juga turut memberikan peran dalam keberhasilan pembelajaran apresiasi cerita pendek. Adapun beberapa peran guru tersebut adalah sebagai berikut:

Pertama, penentuan posisi guru yang fleksibel dapat menciptakan suasana kelas yang kondusif untuk pembelajaran. Kedua, pemberian reward kepada siswa yang aktif dalam kegiatan belajar mengajar dapat memotivasi siswa untuk lebih aktif. Ketiga, sikap guru yang terbuka dan tidak kaku dalam menciptakan suasana kelas yang tidak tegang. Ketiga hal tersebut 
sesuai dengan pendapat Adam dan Decey (dalam Usman, 2005, p. 9) yang menyatakan, "Peranan dan kompetensi guru dalam proses belajar mengajar adalah guru sebagai pengelola kelas. Guru hendaknya bisa mengatur, mengarahkan, dan mengawasi kegiatan belajar mengajar agar terarah kepada tujuan-tujuan pendidikan yang telah dirumuskan.”

Dalam tindakan pertama dan kedua, pembelajaran dilaksanakan di ruang kelas XI IA 1 SMA Batik 1 Surakarta. Ketika itu, hasil yang didapat masih kurang optimal. Hal ini disebabkan, pelaksanaan pembelajaran apresiasi pembacaan cerita pendek membutuhkan lingkungan yang terkondisi dengan baik. Lingkungan tersebut mencakup lingkungan di dalam kelas atau di luar kelas. Oleh karena itu, dalam tindakan ketiga, pembelajaran dilakukan di ruang audio visual (multimedia), ruang tersebut terbukti dapat meningkatkan kualitas pembelajaran apresiasi cerita pendek.

Berdasarkan hasil pengamatan tindakan I, II, dan III dapat dinyatakan bahwa terjadi peningkatan kualitas proses pembelajaran apresiasi cerita pendek bermedia audio berupa pembacaan cerita pendek dari siklus pertama sampai dengan siklus ketiga. Adapun pembahasan peningkatan kualitas proses pembelajaran apresiasi cerita pendek adalah sebagai berikut.

Keberhasilan pemanfaatan media audio dalam meningkatkan kualitas proses pembelajaran apresiasi cerita pendek ini dapat dilihat dari indikator-indikator sebagai berikut:

a) Siswa lebih aktif dalam mengikuti apersepsi

Selama pelaksanaan tindakan sejak siklus pertama hingga ketiga, terjadi peningkatan yang signifikan dalam hal antusias siswa mengikuti kegiatan apersepsi. Hal ini terbukti bahwa dalam siklus pertama sebanyak 46\% (14 siswa dari 31 siswa) yang aktif mengikuti apersepsi. Pada siklus kedua, sebanyak 71\% (22 siswa dari 31 siswa) yang aktif mengikuti apersepsi. Keaktifan tersebut semakin meningkat dalam pelaksanaan siklus ketiga, sebanyak 81\% (25 siswa dari 31 siswa) yang antusias mengikuti apersepsi.

b) Siswa lebih aktif dalam mengikuti kegiatan belajar-mengajar

Pemanfaatan rekaman pembacaan cerita pendek sebagai media pembelajaran dalam pembelajaran apresiasi cerita pendek merupakan hal yang baru bagi siswa di SMA Batik 1 Surakarta. Oleh karena itulah, inovasi dalam pembelajaran apresiasi cerita pendek tersebut disambut dengan antusias tinggi oleh siswa. Tolok ukur yang menyatakan tingginya antusias siswa tersebut adalah hasil observasi selama kegiatan belajar-mengajar berlangsung yang menunjukkan peningkatan pada tiap siklus. Pada siklus pertama, keaktifan siswa selama mengikuti kegiatan belajar-mengajar sebesar 61\% (19 siswa dari 31 siswa). Pada siklus kedua, persentase keaktifan siswa tersebut meningkat menjadi 75\% (23 siswa dari 31 siswa). Peningkatan keaktifan siswa tersebut meningkat drastis pada siklus 
ketiga, menjadi 87\% (27 siswa dari 31 siswa).

c) Siswa tidak merasa malu lagi untuk menyampaikan hasil pekerjaan mereka dalam forum diskusi

Selama pembelajaran apresiasi cerita pendek dengan memanfaatkan media audioberupa rekaman pembacaan cerita pendek berlangsung, siswa merasa terpacu untuk berkompetisi dengan siswa lain. Kondisi ini membuat siswa tidak lagi enggan untuk menyampaikan hasil pekerjaannya dalam forum diskusi yang dibuka guru. Pernyataan di atas terbukti dengan meningkatnya keberanian siswa beraktualisasi dalam mengikuti diskusi. Pada siklus pertama, siswa yang berani beraktualisasi dalam diskusi sebesar 20\% (6 siswa dari 31 siswa). Pada siklus-siklus selanjutnya terus mengalami peningkatan yang signifikan. Peningkatan tersebut sebesar 52\% (16 siswa dari 31 siswa) pada siklus kedua, dan $71 \%$ (22 siswa dari 31 siswa) pada siklus ketiga.

Pernyataan tersebut secara rinci dijelaskan dalam tabel persentase peningkatan kualitas proses pembelajaran apresiasi cerita pendek berikut ini.

\begin{tabular}{|l|l|c|c|c|}
\hline \multirow{2}{*}{ No. } & \multicolumn{1}{|c|}{ Kegiatan Siswa } & \multicolumn{3}{|c|}{ Persentase } \\
\cline { 3 - 5 } & \multicolumn{1}{|c|}{} & Siklus 1 & Siklus 2 & Siklus 3 \\
\hline 1. & Aktif selama apersepsi & $46 \%$ & $71 \%$ & $81 \%$ \\
\hline 2. & Aktif selama mengikuti pelajaran & $61 \%$ & $75 \%$ & $87 \%$ \\
\hline 3. & $\begin{array}{l}\text { Berani membacakan hasil pekerjaan dalam forum } \\
\text { diskusi }\end{array}$ & $20 \%$ & $52 \%$ & $71 \%$ \\
\hline
\end{tabular}

Tabel 2. Persentase Peningkatan Kualitas Proses Pembelajaran Apresiasi Cerita pendek

\section{Kesimpulan}

Penelitian ini memberi gambaran yang jelas bahwa keberhasilan proses pembelajaran tergantung padabeberapa faktoryang saling berhubungan satu samalain. Faktor-faktortersebut berasal dari guru, siswa, dan lingkungan belajar. Faktor dari pihak guru yaitu kemampuan guru dalam mengembangkan strategi dan metode pembelajaran, kemampuan guru dalam mengembangkan dan menyajikan materi, kemampuan guru dalam mengembangkan media pembelajaran, serta kemampuan guru dalam mengelola kelas. Faktor dari pihak siswa yaitu antusias dan keaktifan siswa dalam mengikuti proses pembelajaran. Faktor lingkungan yaitu terciptanya situasi belajar menyimak yang kondusif sehingga siswa dapat berkonsentrasi dalam memahami apa yang mereka simak.

Faktor-faktor yang telah disebutkan di atas hendaknya diupayakan dengan maksimal agar kegiatan belajar-mengajar mengalami peningkatan baik dalam proses ataupun hasilnya. Apabila guru memiliki kemampuan yang dalam menyampaikan materi, mengelola kelas, menerapkan metode belajar yang sesuai, memanfaatkan media yang sesuai dan mewujudkan lingkungan belajar yang kondusif, maka guru akan dapat melaksanakan pembelajaran dengan 
baik. Siswa juga akan termotivasi untuk mengikuti kegiatan belajar mengajar dengan aktif.

Adapun beberapa simpulan yang dapat dihasilkan dari penelitian ini bahwa pemanfaatan media audio berupa rekaman pembacaan cerita pendek dapat meningkatkan kualitas proses pembelajaran apresiasi cerita pendek pada siswa kelas XI SMA Batik 1 Surakarta.

Upaya-upaya yang ditempuh untuk meningkatkan kualitas proses pembelajaran apresiasi cerita pendek tersebut adalah sebagai berikut:

a. Pemanfaatkan media audio berupa rekaman pembacaan cerita pendek dalam pembelajaran apresiasi cerita pendek.

b. Pemberian reward kepada siswa sehingga memacu siswa untuk aktif selama proses pembelajaran.

Berbagai upaya yang dilakukan dalam penelitian ini terbukti dapat meningkatkan kualitas proses pembelajaran apresiasi cerita pendek di kelas XI SMA Batik 1 Surakarta. Hal tersebut terefleksi dari peningkatan beberapa indikator di bawah ini:

a. Meningkatnya keaktifan siswa selama mengikuti kegiatan apersepsi.

b. Meningkatnya keaktifan siswa selama mengikuti kegiatan belajar-mengajar.

c. Meningkatnya keberanian siswa untuk mengemukakan hasil pekerjaannya dalam forum diskusi yang dibuka guru.

\section{Referensi}

Arikunto, S. (2007). Dasar-dasar Evaluasi Pendidikan (Revisi). Jakarta: Bumi Aksara.

Hamalik, O. (2003). Kurikulum dan Pembelajaran. Jakarta: Bumi Aksara.

Ismail, T. (2007). Mengasah Ketajaman Intuisi dan Kepekaan Sosial melalui Kegemaran Membaca Karya Sastra. In Makalah Seminar Nasional dan Pencanangan Kampanye Ayo Giat Membaca. Surakarta, 20 Maret 2007.

Lickona, T. (2013). Pendidikan Karakter: Panduan Lengkap Mendidik Siswa Menjadi Pintar dan Baik. Bandung: Nusamedia.

Madya, S. (2006). Teori dan Praktik Penelitian Tindakan (Action Reserch). Bandung: Alfabeta.

Muqtadir, I. A. (2008). Wisdom of Luqman El-Hakim: 12 Cara Membentengi Kerusakan Akhlak. Solo: Aqwam.

Nurgiyantoro, B. (2005). Teori Pengkajian Fiksi. Yogyakarta: Gadjah Mada University Press.

Safitri, E. M. (2013). Meningkatkan Kemampuan Melafalkan Surat Pendek Melalui Media Audio dengan Teknik Murottal pada Anak Kelompok B TK Hasyim Asy’ari Surabaya. PAUD Teratai: Jurnal Ilmiah Pendidikan Anak Usia Dini, 2(1), 1-5.

Suhardjono. (2006). Penelitian Tindakan Kelas. Jakarta: Bumi Aksara.

Usman, M. U. (2005). Menjadi Guru Profesional. Bandung: PT. Remaja Rosdakarya.

Wijayanti, D. M. (2016). Inovasi Model Pembelajaran Apresiasi Geguritan : Studi Kasus SDN Sampangan , Kota Semarang. Buana Gender, 1(1), 91-97. 